\title{
Syngenetic inclusion bearing diamonds from Letseng-la-Terai, Lesotho.
}

Mc Dade, P. ${ }^{1}$ and Harris, J.W. ${ }^{2}$

1.Department of Geology \& Geophysics, University of Edinburgh, Edinburgh, EH9 3JL, U.K.;

Paula.McDade@glg.ed.ac.uk

2. Department of Geology \& Applied Geology, University of Glasgow, Glasgow, G12 8QQ, U.K.

An integrated study of syngenetic inclusion mineralogy and chemistry, coupled with the determination of $\delta^{13} \mathrm{C}$ and nitrogen content and aggregation state of encapsulating diamond from Letseng-la-Terai, reveal a chemically diverse diamond suite recording a complex mantle history beneath the south-eastern margin of the Kalahari Craton. Peridotitic, eclogitic, websteritic, sulphide and ferropericlase assemblages are present, together with diamond and calcite inclusions which are of undefined paragenetic type.

\section{Inclusion assemblages.}

The peridotitic phases garnet (grt), orthopyroxene (opx) and chromite (chr) all occur by themselves or with olivine (ol). In addition a grt+opx pair and a grt+opx+ol triplet are present in separate stones, all phases non-touching. Websteritic grt occurred by itself or with clinopyroxene (cpx). An opx-cpx-ol assemblage, is also classified as websteritic. The eclogitic inclusions found are grt and coesite, but they were in separate diamonds. Sulphide, ferropericlase and diamond all occur by themselves. Calcite occurs by itself and with olivine.

\section{Inclusion chemistry.}

All inclusions were recovered subsequent to diamond breaking. Garnets of peridotitic (all harzburgitic), websteritic and eclogitic parageneses fall within the bounds of previously published analyses of syngenetic garnet inclusions worldwide (Figure 1). Olivine compositions which range from Fo93.1 to Fo95.2, plot at the magnesian end of the worldwide composition range (Figure 2). The main population of opx are also relatively magnesian (Figure 3 ), the exception being the websteritic opx at $\mathrm{En}_{81.1}$. $\mathrm{Cr}_{2} \mathrm{O}_{3}$ contents in chromites are in the range 60.5 to $66.2 \mathrm{wt} \%$ with $\mathrm{F} / \mathrm{FM}\left(\mathrm{Fe}^{2+} / \mathrm{Fe}^{2+}+\right.$ $\mathrm{Mg}$ ) ratios of $0.29-0.32$. Both cpxs are omphacitic. The single sulphide is bimineralic, composed of pyrite exsolving from a monosulphide solid solution. The lone ferropericlase of $\mathrm{Mg \#} 89.0$ contains $1.7 \mathrm{wt} \% \mathrm{NiO}$ and $0.3 \mathrm{wt} \% \mathrm{Na}_{2} \mathrm{O}$ as the main impurities. Both the coesite and calcite inclusions are almost pure end member phases.

\section{Inclusion disequilibrium.}

Two diamonds bore inclusion assemblages with disequilibrium compositions. A harzburgitic stone yielded two discrete garnets with a difference of 6.04 wt $\%$ in $\mathrm{Cr}_{2} \mathrm{O}_{3}$ and $1.29 \mathrm{wt} \%$ in $\mathrm{CaO}$. The websteritic assemblage opx-cpx-ol, yielded an opx $\left(\mathrm{En}_{81.1}\right)$ chemically distinct from peridotitic opxs, whilst the olivine ( $\mathrm{Fo}_{93.1}$ ) was indistinguishable from the peridotitic population.

\section{$\delta^{13} \mathrm{C}$ signatures.}

The $\delta^{13} \mathrm{C}$ diamond compositions, summarised in Figure 4, spanned a wide range (-18 to $-2 \%$ ), but no obvious correlation between the inclusion chemistry and the $\delta^{13} \mathrm{C}$ signatures, was noted. 


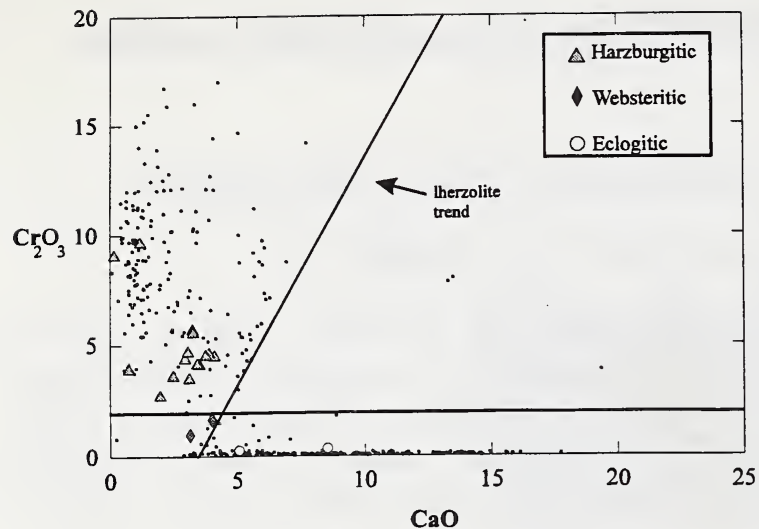

Figure 1. $\mathrm{CaO}$ vs $\mathrm{Cr}_{2} \mathrm{O}_{3}$ plot of Letseng garnet inclusions with parageneses as shown. Small circles represent previously published inclusion analyses from the database compiled by Stachel and Harris (1997).

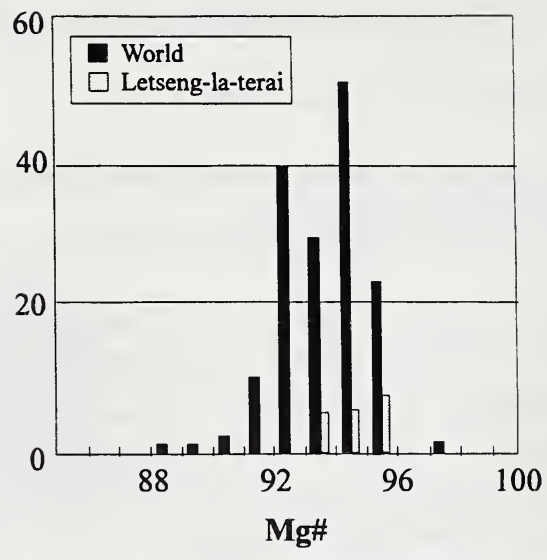

Figure 2. Olivine compositions from Letseng compared to those from pre-existing analyses compiled by Stachel and Harris (1997).

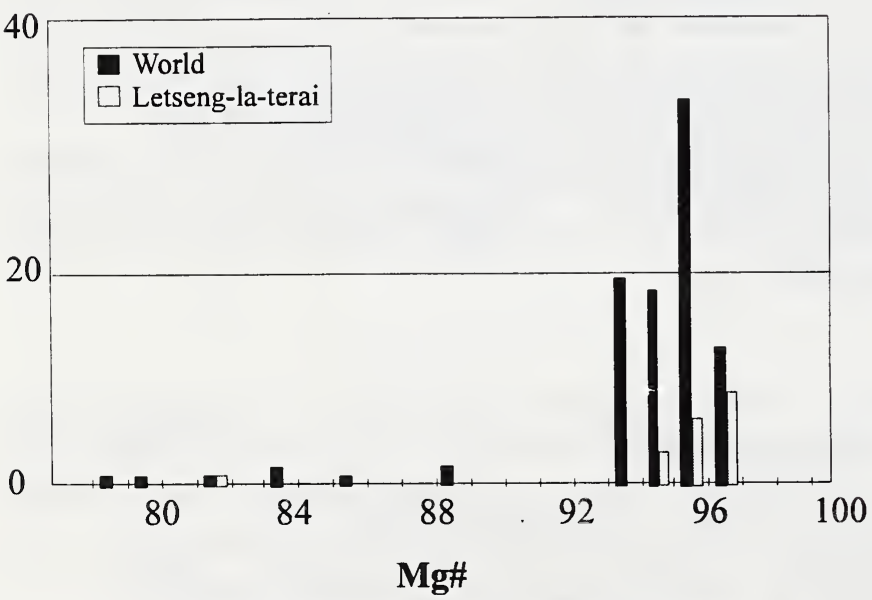

Figure 3. Orthopyroxene analyses from Letseng inclusions compared with pre-existing analyses compiled by Stachel and Harris (1997).

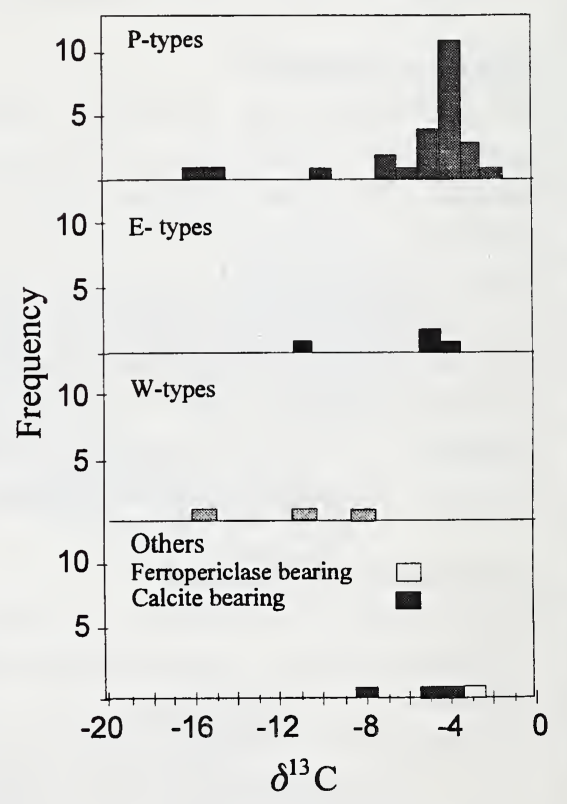

Figure 4. Variation of $\delta^{13} \mathrm{C}$ signature of diamond host with inclusion chemistry.

\section{Aggregation states and contents of nitrogen.}

Fourier Transform Infrared Spectroscopy (FTIR) on 31 diamonds with suitable cleavage chips upon inclusion breakout, yielded the nitrogen aggregation state and subsequently, the nitrogen contents. Ten diamonds are Type II (i.e. devoid of nitrogen); 9 of these contained peridotitic inclusions, the 
tenth being the diamond with ferropericlase. Of the remainder, 2 diamonds are IaA, 3 are IaA-p (i.e IaA with platelets), 3 are $I a A B, 22$ are IaAB-p and 1 is IaB. Hydrogen was detected in three diamonds, all Type IaAB-p. Nitrogen contents ranged between 18 and 1003 atomic ppm in the Type I diamonds. There is no correlation between the nitrogen aggregation state and content and the diamond paragenesis type or $\delta^{13} \mathrm{C}$ value.

\section{Geothermobarometry.}

Peridotitic inclusion assemblages yield equilibration temperatures of $1125^{\circ} \mathrm{C}$ to $1236^{\circ} \mathrm{C}$ for grt+opx pairs (Harley, 1984), and $1250^{\circ} \mathrm{C}$ to $1354^{\circ} \mathrm{C}$ for grttol pairs (O'Neill and Wood, 1979; O'Neill, 1980). Temperature variations of up to $50^{\circ} \mathrm{C}$ were recorded by a multiple grt+opx bearing diamond. Calculated pressures ranged between 52 kbars and 68 kbars (Brey and Köhler, 1990). Websteritic equilibration temperatures were $1259^{\circ} \mathrm{C}$ for the grt+opx assemblage and $1323^{\circ} \mathrm{C}$ using the $\mathrm{Ca}$ in opx thermometer of Brey and Köhler (1990).

\section{Conclusions.}

The Letseng-la-Terai diamond suite shows some striking similarities to those from the mines at Koffiefontein, Jagersfontein (Deines et al., 1991) and Monastery (Moore and Gurney, 1986), which are all situated on the Kalahari craton edge. The disequilibrium inclusion compositions, variation in equilibration temperatures and the wide range of $\delta^{13} \mathrm{C}$ values could be interpreted as evidence of multistage diamond growth and resorption over a prolonged time interval, within a single host lithology undergoing modal metasomatism as a result of melt percolation. However, disequilibrium is only observed in two of the diamonds, and the degree of metasomatism required for such dramatic changes to a host rock lithology has not so far been observed in mantle xenoliths. A more feasible explanation for this diverse diamond suite is that the Letseng kimberlite sampled multiple diamondiferous horizons during eruption. This varied mantle stratigraphy was also sampled by the neighbouring craton-edge kimberlites.

\section{References.}

Brey, G.P., and Köhler, T., 1990. Geothermobarometry in four-phase lherzolites II. New thermobarometers, and practical assessment of existing thermobarometers. J. Petrology, 31, p. 1353 $-1378$.

Deines, P., Harris, J.W. and Gurney, J.J., 1991. The carbon isotopic composition and nitrogen content of lithospheric and astheospheric diamonds from Jagersfontein and Koffiefontein kimberlite, South Africa. Geochim. Cosmochim. Acta, 55, p 2615-2625.

Harley, S.L., 1984. An experimental study of the partitioning of iron and magnesium between garnet and orthopyroxene. Contrib. Mineral. Petrol., 86, p. 359 - 373.

Krogh, E.J., 1988. The garnet-clinopyroxene iron-magnesium geothermometer - a reinterpretation of existing experimental data. Contrib. Mineral. Petrol., 99, p. 44 - 48.

Moore, R.O., and Gurney, J.J., 1986. Mineral inclusions in diamond from the Monastery kimberlite, South Africa. In Ross, J., (ed.) Kimberlites and Related Rocks (Volume 2). GSA Special Publication, Blackivell Scientific Publications No. 14, p 1030 - 1041.

O'Neill, HStC., 1980. An experimental study of the iron-magnesium partitioning between olivine and its calibration as a geothermometer: corrections. Contrib. Mineral. Petrol., 72, p. 37.

O'Neill, HStC. and Wood, B., 1979. An experimental study of Fe-Mg partitioning between garnet and olivine and its calibration as a geothermometer. Contrib. Mineral. Petrol., 70, p. 59-70.

Stachel, T. and Harris, J.W., 1997. Syngenetic inclusions in diamond from the Birim field (Ghana) - a deep peridotitic profile with a history of depletion and re-enrichment. Contrib. Mineral. Petrol., 127 , p. $336-352$. 